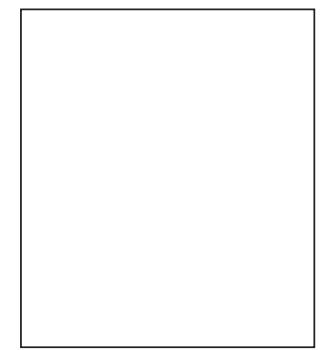

\title{
Koulutuksen yhtenäisyys ja erilaisuus yhdentyvässä Euroopassa
}

\begin{abstract}
"Maastrichtin sopimuksen mukaisten, koulutuspolitiikan kehitystä koskevien päätösten täytyy löytää paikkansa siinä jännitteessä, mikä vallitsee unionin uusien vastuualueiden sekä jäsenvaltioiden perustuslaillisesti ja lainmukaisesti identifioitujen oikeuksien välillä. Theo M.E. Liket on selkiyttänyt tämän ongelman kysymykseksi, ovatko koulut ja muut koulutuslaitokset viimeisiä kansallisvaltion linnoituksia ja jäävätkö ne sellaisiksi ylikansallisia instituutioita ja kansainvälisiä talousverkostoja vastaan."
\end{abstract}

Jos minua olisi 1980-luvun loppupuoliskolla pyydetty käsittelemään koulutuksen yhtenäisyyttä ja erilaisuutta yhdentyvässä E uroopassa, käsitteellinen lähestymistapani olisi täysin poikennut siitä, mitä nyt esitän. On totta, ettei viime vuosikymmenen lopulla eurooppalainen orien-toituminen olisi ollut yhtä epäröivää ja varovaista kuin vielä vuosikymmenen puolivälissä. O lisin kuitenkin korostanut enemmän mahdollisuuksia ja toiveita.

Vuosikymmenen taitteessa tilanne oli kuitenkin täysin muuttunut. Berliinin muuri oli murtunut ja samettivallankumoukset, Vaclav $\mathrm{H}$ avelin symbolista luonnehdintaa käyttäen, tapahtuivat useimmissa K eski-Euroopan maissa. $\mathrm{N}$ uo vuodet olivat täynnä innostusta kommunistisen hallitustavan sortumisen jälkeen ja täynnä odotuksia uudesta ja paremmasta tulevaisuudesta.

$\mathrm{N}$ yt, kahdeksan vuotta myöhemmin, näyttämö on muuttunut uudestaan. Toisaalta 80-luvun loppupuolen ja 90-luvun alkupuolen suuri mullistus on osoittautunut peruuttamattomaksi ja monet tapahtumat ja trendit viittaavat siihen, että aikaisemmin kommunistiset maat näyttävät olevan matkalla parempaan. Toisaalta ei voi jäädä huomaamatta, että hyvinvoinnin tunne on ohi ja että joidenkin äskettäin perustettujen demokratioiden on vaikeaa päästä eteenpäin. Joidenkin K eski- ja I tä-E uroopan maiden aikaisemmat hallitukset ovat palanneet valtaan, ei 
kuitenkaan vanhassa merkityksessä. Siksi radikaalit muutokset I tä-E uroopassa 80-luvun lopussa ja länsi-itä-konfliktin häviäminen ovat avanneet uusia ääriviivoja laajemmalle Euroopalle.

Samaan aikaan kun I tä-Euroopan radikaalit muutokset tapahtuivat, maanosamme läntisten osien kehitys oli myös jännittävää, vaikka ei yhtä silmiinpistävää ja myrskyisää kuin idässä.

80-luvun lopussa Euroopan yhteisö (silloinen $E Y)$ alkoi määrätietoisesti edetä kohti integraatiota ja päätyi Maastrichtin sopimukseen vuoden 1992 lopussa. Tämä sopimus on avannut uusia ulottuvuuksia sekä vanhoille että uusille jäsenvaltioille, Suomi mukaan lukien. $\mathrm{K}$ aiken kaikkiaan siis Eurooppa on astunut omassa historiassaan uuteen aikakauteen ja poliittiset, sosioekonomiset ja kulttuurilliset muutokset ovat vaikuttaneet olennaisesti koulutukseen niin akateemisilla kuin ei-akateemisilla aloilla.

K äsitteeseen E urooppa ei sisälly hegemonisia, puhumattakaan imperialistisia vaatimuksia. Termiä käytetään vain työkäsitteenä korostamaan entisten itäblokin maiden paluuta E uroopan vapaiden kansakuntien joukkoon. Tässä mielessä Eurooppa-termi ilmaisee kolmatta E uroopan ulottuvuutta, ensimmäisenä dimensioina EU-Eurooppa ja toisena E uroopan neuvosto, eli tilannetta vuoteen 1990 asti. Sillä välin toinen dimensio on laajentunut $\mathrm{K}$ eski-E Uroopan, osittain $\mathrm{K}$ aakkois-E uroopan maihin ja Venäjälle, josta on tullut Euroopan neuvoston täysjäsen. (E uroopan neuvoston ulkopuolella ovat ainakin toistaiseksi K aukasian valtiot, Serbia, Bosnia ja Valko-Venäjä; toimituksen lisäys). N euvostoliiton sortuminen, rauhalliset vallankumoukset ja mullistukset keskeisessä I tä-E uroopassa ja vähäisemmässä määrin viimeaikaiset muutokset $\mathrm{K}$ aakkois-E uroopassa ovat saaneet aikaisemman länsi-itä -erottelun näyttämään kyseenalaiselta. Länsi ja itä -käsitteet ovat menettäneet selkeät, niiden rajalinjojen laillistamat merkitykset, jotka poliittinen ja sotilaallinen valtarakenne määräsi yhtenä tärkeimmistä ja epäinhimillisimmistä toisen maailmansodan seurauksista.
Se, että sodanjälkeinen jakaantuminen on hävinnyt, ei tietystikään tarkoita sisäisten rajalinjojen ja jännitteiden pyyhkiytymistä pois Euroopan sisällä. E urooppa on ollut maanosa, missä yhtenäisyyden ja erilaisuuden välinen kahtiajako on ollut aina merkittävä. Sen lisäksi E uroopan rajoista on aina kiistelty. Lounaisraja on määräytynyt E spanjan vallanvaihdosta (reconquista) lähtien. Euroopan itärajan määrittäminen on kuitenkin osoittautunut paljon monimutkaisemmaksi. Maantiede ei tarjoa mitään Iuonnollista rajaviivaa, vaikka Uralia on pidetty näihin päiviin saakka kuviteltuna rajana esimerkiksi maantieteen tutkimuksissa ja tekstikirjoissa ja myös poliitikkojen yksinkertaistamissa iskulauseissa.

$\mathrm{N}$ ykyään kukaan ei aseta kyseenalaiseksi kaikkien niiden kansakuntien "eurooppalaisen identiteettiä", joiden kulttuuriset identiteetit juontavat katolisesta ja protestanttisesta kristillisyydestä. Tämä näkemys sisällyttää mitä todennäköisimmin mukaan myös K aakkois-Euroopan ortodoksimaat. Ristiriitaisia väitteitä herättävät muslimit; he ovat asuneet $\mathrm{K}$ aakkois- $\mathrm{E}$ uroopassa vuosisatoja. O ma lukunsa on kahdelle mantereelle ulottuva Turkki. Emme voi myöskään ohittaa entisen Jugoslavian, erityisesti Bosnian ja Albanian sekä Bulgarian muslimeja. Tosiasia on myös, että muslimit asuvat ja ovat asuneet jo vuosia siirtolaisina myös länsieurooppalaisissa maissa, I sossa Britanniassa ja Ranskassa.

Pitäisikö siis $\mathrm{N}$ euvostoliitosta eronneet osavaltiot sijoittaa E urooppaan? K ysymyksellä on pitkä historia aina keskiajalta asti, uudenaikaisessa mielessä Pietari Suuren ajasta asti. 1800- ja 1900-luvulta alkaen Venäjän, Ukrainan ja Valko-Venäjän ja myös G eorgian ja Armenian lukeminen laajempaan Eurooppaan kuuluvaksi on aiheuttanut jatkuvaa ja terävää keskustelua sekä syntyperäisten kansalaisten että ulkomaalaisten keskuudessa. K eskustelu on saavuttanut todellista merkitystä näinä aikoina, puhumattakaan Balttian kansoista, joiden paikkaa E uroopassa ei koskaan ole asetettu kyseenal aiseksi. 
Venäläisyyden sisällä zapadnikien (länsimielisten) ja slavonofiilien välinen kiihkeä keskustelu on aina ollut tärkeä ja kuvaava esimerkki identiteetin etsinnästä. Venäjällä esiinnoussut monikansallinen (ja monikulttuurinen) rakenne näyttää tekevän eurooppalaisuuden monimutkaisemmaksi miellettäväksi, kun ajatellaan entisen $\mathrm{N}$ euvostoliiton aasialaisia tasaval toja ja väliaikaisen I tsenäisten valtioiden yhteisön (IVY) kansallisuuksia. VaikkaVenäjän federaatio on alueellisesti ja väestöllisesti huo mattavasti pienempi kuin Neuvostoliitto, se on perinyt entisen $\mathrm{N}$ euvostoliiton monikansalliset (ja monikulttuuriset) ongelmat. On syytä ottaa huomioon, että Euroopan turvallisuus ja yhteistyöjärjestö (ETY) lukee piiriinsä kaikki entisen $\mathrm{N}$ euvostoliiton tasavallat, myös ne, jotka sijaitsevat K eski-A asiassa. K aiken lisäksi U NE SCO lukee Euroopan alueeksi ei vain entisen $\mathrm{N}$ euvostoliiton alueet, vaan myös USA:n, K anadan ja Israelin. Viimeinen ulottuvuus viittaa historiallisesti ja kulttuurisesti vieläkin laajempaan Eurooppa-dimensioon, mitä tosin käsittelen vain pintapuolisesti lopussa.

U skonnollisella kriteerillä on olennaisesti merkitystä laajemman Euroopan identifioinnille erityisesti siltä osin, kun se ylittää tämän päivän ihmisten sitoutumisen uskontunnustukseen tai kirkkokuntaan (uskonlahkoon). Tässä yhteydessä en paneudu syvemmin muslimikysymykseen. Kristinuskoon ei kuulu ainoastaan kiihkottomia ja yksinomaan rekisteröityjä (kirjattuja) kirkonjäseniä, vaan myös agnostikkoja, jotka on koulutettu kristillisen kulttuurin ja perinteen muovaamassa ympäristössä. $N$ äin eurooppalainen kristillinen aines on vaikuttanut perillisiinsä tähän päivään asti. Se tulee ilmi humanismin, rationalismin, valistuksen ja modernin demokratian välisessä vuorovaikutuksessa. Juuri tämä liikkuva ja samanaikaisesti heilahteleva vuorovaikutus tuo esiin yhtenäisyyden ja erilaisuuden periaatteet ja sen pysyvän jännityksen, mihin ne ovat kietoutuneet. Tämän kudoksen keskeltä löydetään E uroopan valtioiden erikoishalu valloittaa muu maailma ja sen lisäksi alistaa valtaansa ihmisen elävä ja eloton ympäristö. Vuosisatamme lähetessä loppuaan molemmat lähestymistavat ovat yhä enenevässä määrin hälyyttävällä voimalla vallanneet tietoisuuttamme ja konkreettista olemassaoloamme.

M eidän täytyy siis olla tietoisia, mitä tarkoitamme puhuessamme Euroopasta: puhummeko siitä talouden, sosiaalipolitiikan, kulttuurin, filosofian vai koulutuksen ehdoin. 0 n itsestään selvää, että nämä Euroopan monet kasvot vaikuttavat sisäisten rakenteiden tunnistamisessa, kun ne yhdistetään yhteiskunnallisiin alueisiin (tai alajärjestelmiin) luetelluilla alueilla. Y leisesti todetkaamme, että poliittisesti ja ideologisesti hallitun länsi-itä -rajalinjan murtuminen on osoittanut tien uusille rajalinjoille mantereella. Joissakin tapauksissa ne myötäilevät vanhoja, toisen maailmansodan jälkeiseltä ajalta säilyneitä malleja ja kokevat meidän aikanamme uudelleentulemisensa. Esimerkiksi esiin pulpahtaa uutta keskustelua K eski-E uroopasta, jolloin käsitteen käyttäjät ovat hyvin erimielisiä määritellessään "K eski-E uroopan" rajoja. Sitä paitsi entisen länsi-itä -konfliktin häviäminen on aiheuttanut uusia ongelmia, joista on repäisevänä esimerkkinä viimeaikainen ja yhä lisääntyvä ihmisten muuttaminen tähänastisten läntisten ja itäisten maiden rajojen yli. Tiedostamme myös etniset ryhmät, joilla ei ole omaa kotimaata. E rityisesti romaanit ovat muuttaneet Romaniasta ja entisestä Jugoslaviasta länteen, ennen muuta Saksaan.

E urooppalaisten etsiessä epävakaisuudessaan keinoja parempaan tulevaisuuteen taloudelliset, sosiaalipoliittiset ja kulttuuriset näkymät viestittävät integraatiopyrkimyksistä enemmässä tai vähemmässä määrin. N ämä pyrkimykset kulminoituvat Euroopan suurten yhteenliittymien, Euroopan unionin ja Euroopan neuvoston politiikassa. Sen vuoksi haluan kiinnittää seuraavassa huomiota näiden yhteisöjen toimintaan.

\section{Koulutuspolitiikka Euroopan Unionissa}

M aastrichtin sopimus on ollut voimassa marraskuun 1. päivästä 1993 lähtien. Ensimmäistä kertaa E uroopan yhteisön ( $M$ aastrichtin jälkeen 
nimi muutettiin Euroopan Unioniksi) virallinen asiakirja sisältää koulutusjärjestelmää koskevat ammatilliset ja yleiset alueet sekä velvoittaa jäsenvaltiot kehittämään yhteisiä päämääriä. K oulutuksen uusi suuntaus on kirjattu artiklaan 126, jossa korkealaatuinen koulutus nähdään selkeästi Euroopan politiikan tulevaisuudenkuvana ja jossa Euroopan Unioni velvoitetaan myötävaikuttamaan korkealaatuisen koulutuksen toteutumiseen. $\mathrm{N}$ äin uudet sopimukset menevät yli sen kompetenssin, joka Euroopan yhteisöllä on ollut ammatillisessa ja korkeammassa koulutuksessa. Ammatillista koulutusta koskevat vastaavat ohjeet ja suositukset oli sisällytetty Yhteisön taloudellisia päämääriä sisältäviin asiakirjoihin. Niissä on korostettu liikkuvuuden edistämistä, mikä on vahvistettu myös Maastrichtin sopimuksella. Toisaalta uudet sopimukset korostavat koulutusjärjestelmän erikoisasemaa artiklan 126 lisäksi myös ammatillista koulutusta käsittelevässä artiklassa 127. M yös artiklan 121 mukaista sitoumusta voidaan pitää koulutusvaatimuksia korostavana tehtävänä. Se johtaa Euroopan Unionin jäsenvaltioiden kulttuurien esittelyyn niiden kansallisen ja alueellisen erilaisuuden säilyttämisen ja yleisen kulttuuriperinnön korostamisen mukaisesti.

Euroopan unioni on näin ohittanut taloudellisen yhteisön rajoituksensa ja edennyt kohti koulutuksen ja kulttuurin yhteisöä (Hochbaum 1994, 1). Maastrichtin sopimukseen kohdistuneissa kommenteissa Euroopan Unionin elimille asetetaan kuitenkin rajoja koskien unionin koulutusvaatimuksien täytäntöönpanoa. K oulutusjärjestelmän yleissivistävän alueen o salta tämä tarkoittaa sitä, että jäsenvaltioiden vastuu sekä opetussuunnitelmien sisällöistä että koulutusjärjestelmien rakenteista on tarkan huomion kohteena. K aikenlainen jäsenvaltioiden Iaillisten ja hallinnollisten normien yhteensovittaminen on toimivallan ulkopuolella. Y leissivistävän ja jatkossa myös korkeamman koulutuksen piirissä Euroopan unionin vaatimukset rajoittuvat näin edistämiseksi ja rohkaisemiseksi.

A mmatillisessa koulutuksessa unionin vaati- mukset ovat kuitenkin laajemmat sikäli, että artikla 127 antaa E uroopan unionille tehtäväksi toteuttaa omia toimenpiteitä. Koska myös ammatillisessa koulutuksessa on korostettu jäsenvaltioiden vastuuta sisällöstä ja rakenteesta, saksalainen ekspertti Ingp Hochbaum on esittänyt sen johtopäätöksen, että näin eurooppalaisen koulutuspolitiikan uusi suunta on alistettu uusille rajoituksille ammattikoulutuksessa silloin, kun Euroopan komission johtama käytännön politiikka oli tähän asti jo ulottunut laajemmalle. (H ochbaum 1993, 21).

$\mathrm{K}$ ansallisten koulutuspolitiikkojen etuoikeus Euroopan unionin vaatimuksiin nähden perustuu subsidiariteetin periaatteelle, johon jäsenvaltiot ovat itsensä velvoittaneet. Maastrichtin sopimuksen uusi artikla 3 määrittelee tämän läheisyysperiaatteen seuraavasti:

"Y hteisö toimii sille tällä sopimuksella annetun toimivallan ja asetettujen tavoitteiden rajoissa. A loilla, jotka eivät kuulu yhteisön yksinomaiseen toimivaltaan, yhteisö toissijaisuusperiaatteen mukaisesti toimii vain siinä tapauksessa ja siinä laajuudessa kuin jäsenvaltiot eivät voi riittävällä tavalla toteuttaa suunnitellun toiminnan tavoitteita, jotka suunnitellun toiminnan laajuuden tai vaikutusten takia voidaan tämän vuoksi toteuttaa paremmin yhteisön tasolla. Y hteisön toiminnassa ei saada ylittää sitä, mikä on tarpeen tämän sopimuksen tavoitteiden saavuttamiseksi."

Y hteenvetona näistä ajatuksista voidaan havaita, että Maastrichtin sopimuksen mukaisten koulutuspolitiikan kehitystä koskevien päätöksien täytyy löytää paikkansa siinä jännitteessä, mikä vallitsee unionin uusien vastuualueiden sekä jäsenvaltioiden perustuslaillisesti ja lainmukaisesti identifioitujen oikeuksien välillä. Theo M.E. Likđ on selkiyttänyt tämän ongelman kysymykseksi, ovatko koulut ja muut koulutuslaitokset viimeisiä kansallisvaltion linnoituksia ja jäävätkö ne sellaisiksi ylikansallisia instituutioita ja kansainvälisiä talousverkostoja vastaan. H änen vastaustaan "kyllä ja ei" voidaan pitää ennakoivana viittauksena niille haasteille, jotka koskevat koulutuspolitiik- 


\section{ARाাKस}

kaa Euroopan Unionin sisällä. (Liket 1993, 43.) "K yllä, sikäli kun oma koulujärjestelmä, kieli, kulttuuri-identiteetti ja yliopiston ja koulun pedagogis-didaktiset toimintatavat ovat vakaita laitoksia ja ohjaavat tapaamisia muiden maiden kollegojen kanssa. Ei, sikäli kun tämä perustavaa laatua oleva avoimuus saattaa osaltaan myötävaikuttaa luopumiseen kansallisesta tai nurkkakuntaisesta ahdasmielisyydestä ja yksilöiden tai laitosten rikastuttamiseen toisenlaisilla kokemuksilla."

Tästä jännitteestä keskustellessamme meidät asetetaan ennen kaikkea vastatusten läheisyysperiaatteen kanssa. $\mathrm{N}$ iinpä tämä periaate tulee tärkeäksi lähitulevaisuudessa ja osoittaa sen, harjoittavatko jäsenvaltiot koulutuspolitiikkaa puolustaen omaansa ja suojautuen unionia vastaan vai tuoko kansallinen koulutuspolitiikka aktiivisen ja kehitystä eteenpäin vievän kontribuution eurooppalaiseen dimensioon. Tämä kehityssuunta on asetettu unionin ensimmäisten päämäärien joukkoon.

Prioriteetin valinta on erityisen tärkeää niissä jäsenvaltioissa, joiden koulutusjärjestelmät on muodostettu federalismin tai ainakin alueellisuuden periaatteen mukaisesti. Tällainen tilanne vallitsee ennen kaikkea Saksassa, mutta se on levinnyt muihinkin maihin, erityisesti Belgiaan ja E spanjaan.

Perustuslailliset ja oikeudelliset säädökset osoittavat vain vastuuongelman muodollisen puolen; ne eivät kuitenkaan selkiinnytä sen käytännöllistä relevanssia poliittisessa järjestelmässä. Se, joka on kiinnostunut näiden määräysten täytäntöönpanosta, ajattelee ehdottomasti taloudellista, sosiaali- ja kokonaispoliittista raamia, joka on sellaisten koulutusjärjestelmän käytännön muutosten taustalla. K asvattajan (sanan laajimmassa merkityksessä) on otettava vakavasti huomioon tämä kaksitasoisuus. A jatuskulku johtaa solidaarisuuden ja liikkuvuuden periaatteeseen, joka on E uroopan yhteisön ja vastaavasti unionin kehityksessä ollut tähän päivään asti tärkeä.

\section{4}

AIKUISKASVATUS 3/98
Mitä tulee "jäsenvaltioiden keskinäiseen solidaarisuuteen", Maastrichtin sopimuksen artikla 2 viitoittaa seuraavat tehtävät, mitkä selvästi ylittävät jo tähän asti olemassa olleiden suhteiden kehykset:

- talouden harmoninen ja tasapainoinen kehittäminen

- vakaa, ei-inflatorinen ja ekologisesti suuntautunut kasvu

- taloudellisten saavutusten jatkuva korkea taso

- korkea työllisyystaso

- huomattava sosiaalisen turvallisuuden määrä (ja)

- elintason ja elämisenlaadun lisääminen.

$\mathrm{N}$ ämä viittaukset heijastavat perustrendejä, jotka välittömästi vaikuttavat talouteen, ympäristöön ja politiikkaan. $\mathrm{N}$ iiden takaa voi havaita koulutukseen kohdistuvat haasteet ja aivan erityisesti näiden trendien vaikutukset teknologiaan ja tieteeseen.

Liikkumuden periaate on tähän päivään saakka ollut tärkeä osa Euroopan yhteisön ja unionin historiassa. Tämän periaatteen laajentunut tulkinta, kuten useat huomattavat E uroopan tuomioistuimen päätökset Strasbourgissa ovat korostaneet, voisi antaa aihetta seuraavalle oletukselle, Hermann Avenariuksen kommentin mukaan. Ei ole kaukana se ajatus, että kaikkea, mikä edistää liikkuvuutta, pitäisi pitää yhteisön asiana: koulutusjärjestelmien samanlaistaminen, todistusten ja diplomien yhdenvertaistaminen, koulutuksen pituuden samanlaistaminen, opetussuunnitelmien sisällön järjestely jne. (A venarius 1989, 13). O n totta, että $M$ aastrichtin sopimus tekee tällaiset oletukset epäuskottaviksi. K uitenkin liikkuvuuden periaatteen täytäntöönpanolla on koulutodellisuudessa todennäköisesti integroiva vaikutus, kun otetaan huomioon Euroopan unionin jatkuva lujittamisprosessi.

\section{Koulutuksen paineet Euroopan Unionissa}

Koulutusrakenteiden kehitystä pidettiin erittäin tärkeänä 70-Iuvulla, kun yhtenäiskoulun ajajat 
taistelivat perinteisen toisenasteen (kaksi- tai kolmijakoisen järjestelmän) puolustajia vastaan. Viime aikoina tämä konflikti on menettänyt aikaisemman merkityksensä. Sen sijaan on kiinnitetty huomiota siihen, mitä tapahtuu koulujen ssälä Erityisesti on oltu kiinnostuneita siellä toimivista inmisistä: rehtoreista, opettajista, oppilaista ja siitä, missä määrin välitön ympäristö on osallisena yksittäisen koulun hengessä. Tämä ei tarkoita kuitenkaan sitä, että rakenteellinen keskustelu julkisen koulutuksen tulevaisuudesta olisi hävinnyt.

Rakenteellisen kehityksen lisäksi op๕ussuunnitedmien uudistusta pidetään erittäin tärkeänä. Tällä alueella pitää tehdä ero puhtaasti kansallisiin tarkkoihin määrittelyihin, jotka 1800-luvulla ja 1900-luvun alkupuoliskolla hallitsivat kansallisvaltioiden lukusuunnitelmia; sanomattakin on selvää, ettei tämä trendi ole vieläkään päättynyt. Tässä yhteydessä on paikallaan seurata englantilaisen pedagogin $M$ artin $M C L$ eanin ajatuksia kansallisesta tietokulttuurista ja sen supistumisesta kognitioiden typologioiksi (MCL ean 1993, 266). N ämä kansalliset tietokulttuurit tarkoittavat vuosisatoja vanhoja perinteitä, jotka tulivat vallitseviksi 1600- ja 1700-luvuilla modernin valtion monopoliaseman kasvun myötä. Valtiomonopoli todensi sen, että lapsen ja nuoren koulunkäynti kansallisessa koulutusjärjestelmässä vaikuttaa hänen tiedonalueisiinsa, ajattelutapaansa, kuten hänen asennoitumiseensa oppimiseen, hänen sosiaaliseen sitoutumiseensa. Tässä yhteydessä tutkimustulokset kulttuurien välisestä oppimisesta ovat erityisesti huomionarvoisia.

$M$ artin MCLean on yhdistänyt typologiansa kansallisista tietokulttuureista kolmeen (MCLean 1990), myöhemmin kahteen luokkaan (M CL ean 1993, 266-270). En paneudu hänen yksityiskohtaisiin määritelmiinsä. K uitenkin haluan korostaa, ettei kansallisia tietokulttuureja (national knowledge cultures), kuten $\mathrm{MCL}$ ean ne määrittelee, pitäisi pitää eristettyinä olomuotoina. N e ovat pikemminkin "eurooppalaisten opetussuunnitelmaperinteiden" manifestaatioita. Siten ne näyttäen tien eurooppalaisen yleistietoon, jonka juuret ovat klassisessa an- tiikissa, kristinuskossa, humanismissa ja valistuksessa. Mallina MCLeanin typologia on hyödyllinen niin kauan, kuin se auttaa analysoimaan opetusuunnitelmien kehittymistä E uroopan mantereella kokonaisuudessaan.

K un $\mathrm{MCL}$ eanin viittaukset eurooppalaiseen yleistietoon siirretään nykypäivän koulutuspolitiikkaan ja opetussuunnitelman kehittämisen todellisuuteen, ne tulevat merkitseviksi opetuksen ja koulutuksen Eurooppa-dimensiolla. Tämä ilmaisu ("European dimension in instruction and education") on Maastrichtin sopimuksessa ja siitä on keskusteltu sen hyväksymisestä lähtien monissa artikkeleissa ja asiakirjoissa. Se tarkoittaa, että koko opetussuunnitelma yleensä ja yksittäiset aineet erityisesti pitäisi kohdistaa seikkoihin, jotka ovat E uroopassa relevantteja. Tällä näkökannalla on arvokomponentti, jonka tarkoituksena on korvata kansallisuusajattelu sitoutumisella yleisiin eurooppalaisiin aatteisiin ja tarpeisiin.

Toisaalta koulutuksen Eurooppa-ulottuvuus on yhteydessä "uudenaikaistamisen" tavoitteeseen ja koskee tieteestä, teknologiasta, taloudesta ja myös ekologiasta nouseviin haasteisiin. 0 petussuunnitelman kehityksessä eurooppalaisen dimension komponentit kristallisoituvat keskusteluksi ydinopetussuunnitemasta, jota voidaan pitää yleissivistyksen (Allgemeinbildung) uudenaikaisena varianttina. K aikkien E uroopan maiden lukusuunnitelmia tarkasteltaessa huomataan, että tämä ydin perustuu äidinkielen, yhden vieraan kielen ja matematiikan opetukseen (nämä kolme ainetta edustavat inhimillisen kommunikoinnin peruskoodeja). $\mathrm{N}$ äitä täydennetään yhdellä luonnontieteellä, historialla ja yhteiskuntatieteillä. U seimmissa maissa liikunta ja uskonnonopetus lisäksi kuuluvat tähän ytimeen. Aineiden yhdistelmä ei sinänsä määrittele ydinopetussuunnitelmaa, vaan se, että ydinopetussuunnitelma täytetään Eurooppasuuntautuneilla sisällöillä.

K eskustelut eurooppalaisesta ulottuvuudesta ja sen vaikutuksista "ydinopetussuunnitelmaan" tuo mukaan kysymyksen toimivasta koulutusjärjestelmien vastaavuudesta, jota on paljon 
pohdittu Brysselissä käydyissä keskusteluissa. On sanomattakin selvää, että liikkuvuuden periaate ja sen merkitys työn järjestelmään ovat vaikuttaneet funktionaalisten vastaavuuksien yksityiskohtaiseen valmisteluun. K eskustelut keskittyvät toisaalta koulun päättötodistuksiin toisenasteen koulutuksen lopussa ja toisaalta yliopistojen ja muiden korkeampien oppilaitosten sekä ammattikoulutuksen tutkintolautakuntien asettamiin pätevyysvaatimuksiin.

Jo 80-Iuvun lopussa E uroopan yhteisö esitti tiettyjä standardeja, joiden piti mahdollistaa kenen tahansa pätevän henkilön työn etsiminen toisesta jäsenvaltiosta tulematta syrjityksi. $N$ ämä säädökset sisältävät esimerkiksi opettajat. N ykyään nuori mies tai nainen, joka on hankkinut opettajan pätevyyden Ranskassa, on periaatteessa vapaa hakemaan tointa vaikka Saksasta, sillä ehdolla, että hän osaa saksaa ja täyttää tietyt säädökset, jotka kuuluvat luonnostaan saksalaiseen koulutusjärjestelmään. Tällaiset säädökset koskevat esimerkiksi harjoittelua ja didaktisia opintoja. Vaikeutena on nimityskäytäntö, koska nuorta henkilöä saatetaan pyytää esittämään tiettyjä suorituksia, joihin hänellä ei ole ollut mahdollisuutta kotimaansa koulutuksessa. Joka tapauksessa ovi on auki liikkuvuudelle, eikä ole olemassa mitään olennaista estettä päästä mukaan ja läpäistä estettä.

\section{Euroopan neuvosto ja ohjelmien edistämisen tärkeys}

K oska Euroopan Unioni on alkanut suoranaisesti vaikuttaa jäsenvaltioiden koulutusjärjestelmään ylikansallisena instituutiona, E uroopan neuvoston täytyy tyytyä vaatimattomampaan osaan. Se ei voi enää säätää mitään ohjeellisia asiakirjoja, vaan sen on pitäydyttävä suosituksiin. Tämä ei kuitenkaan merkitse sitä, että tämä organisaatio olisi ollut vailla vaikutusvaltaa. Päinvastoin Euroopan neuvosto on tasoittanut tietä E uroopan mantereen integraatiolle, ensin tuomalla EEC- ja EFTA-maat yhteen, sitten - jo ennen kuin rauta- esirippu murtui - kutsumalla pedagogit maltillisista itäblokin maista, etenkin Unkarista ja Puolasta, konferensseihinsa ja symposioihinsa. Vuodesta 1981 lähtien tämä varhainen aloite on näyttänyt olevan hyvin hedelmällinen. $\mathrm{N}$ ykyään K eski- ja I tä-E uroopan maiden jäsenyyttä Euroopan neuvostossa voidaan pitää, samoin kuin oli EFTA-maiden tapauksessa 70- ja 80-luvuilla, valmistavana askeleena Euroopan U nionin jäsenyyteen, tai laajempaa Eurooppaa ajateltaessa keinona voittaa niiden maiden väliset kuilut, jotka ovat kuuluneet ennen erillään oleviin blokkeihin.

\section{Eurooppakeskeisyys versus maailmanlaajuinen avoimuus}

$\mathrm{K}$ un tutkitaan dokumentteja, joita kansalliset ja eurooppalaiset viranomaiset ja organisaatiot erityisesti Euroopan unionin sisällä ovat julkaisseet, ja vastaavasti kansallisten opetusministerien julkaisemia suosituksia, voi huomata tietynlaista E urooppa-keskeisyyttä, joka on korvannut tähänastiset kansalliset suuntaukset. $K$ riitikot ovat huomauttaneet, että sellaisissa ohjeissa kulttuurien välinen lähestymistapa on usein jätetty huomiotta. Täten he haluavat kiinnitettävän huomiota tarpeeseen avata eurooppalainen dimensio maailmanlaajuiseksi ulottuvuudeksi. Tämä ongelma on saanut lisää relevanssia sen tosiasian myötä, että tänä päivänä monissa $E$ uroopan maissa on ei-eurooppalaista syntyperää olevia inmisiä, joiden lapset ovat kouluiässä.

Kulttuurien välisten koulutusohjelmien lisäksi kysymyksen eurooppalaisesta identiteetistä tulee kokonaisuutena merkitä sitä, ettemme rakenna E urooppaa linnoitukseksi. M eidän on myös muistettava, että Euroopan Unioni ei edusta koko Eurooppaa. Laajemman E uroopan rajat ovat yhä avoinna itään ja kaakkoon. E rityisesti pitää kiinnittää huomiota siihen erityisasemaan, mikä V enäjällä on eurooppalaisia ja aasialaisia kansallisuuksia kattavana valtiona.

Lopuksi haluan tarkastella Euroopan suhdetta Pohjois-A merikkaan. Tämä yhteys perustuu 
molempien mantereiden kulttuuriperintöön sellaisissa eettisissä arvoissa kuten inmisarvo, ihmisoikeudet ja suvaitsevaisuus. Viimeaikoina Pohjois-A merikassa, ennen kaikkea USA :Ssa, on yllättäen löydetty tarvetta kansalliseen identiteettiin. Sen ei kuitenkaan pitäisi merkitä Pohjois-A merikan sulkemista eurooppalaisen keskustelun ulkopuolelle, vaikkakin pääpaino on vanhassa Euroopassa. Ingo H ochbaum on huomauttanut, että "vuonna 2015 teollistuneet demokratiat edustavat vähempää kuin 10 prosenttia maapallon väestöstä; siksi on tarpeellista kysyä, onko länsiarvoilla mahdollisuutta ollenkaan puolustaa oikeuksiaan" (Hochbaum 1994). Tästä pessimistisestä näkymästä huolimatta kaikki Euroopan yksittäiset ryhmät, alueet, valtiot ja valtioryhmät haastetaan etsimään liittolaisia, jotka pitävät uskollisesti kiinni yhteisistä inmisarvoista. O n sanomattakin selvää, että etsimisen täytyy perustua vakaumukselle siitä, että nämä arvot tunnustetaan ja niitä harjoitetaan Euroopassa itsessään. Sitä paitsi maailmanlaajuisen haasteen hyväksyminen olisi tuomittu epäonnistumaan, jos se tapahtuisi linnoittautumismenttaliteetillä. Siinä tapauksessa ei olisi merkitystä, tulisiko tästä mentaliteetista tärkeä alueellisten, kansallisten tai eurooppalaisten rajojen sisällä.

K oulutus sinänsä ei pysty ratkaisemaan ongelmia. Se voi kuitenkin myötävaikuttaa ratkaisujen etsimisessä. M eidän tulisi tiedostaa tämä myötävaikutus suunnitellessamme ja harjoittaessamme koulutusta, joka yhdistää uudenaikaistamisen ja inhimillisyyden niihin kansallisiin, eurooppalaisiin ja universaaleihin vahvuuksiimme, jotka olemme perineet menneisyydestä. Suuntautumalla kohti uusia vaativia tehtäviä meidän tulee määritellä Euroopan paikka huomisen "maailmanlaajuisessa kylässä".

\section{Lähteet}

AVENARIUS, Hermann 1989. Bildung in der Europäischen $\mathrm{G}$ emeinschaft. Zum Verhältnis von europäischem $\mathrm{Gemeinschaftsrecht} \mathrm{und}$ innerstaatlichem Recht (Education in the
E uropean Community, concerning the relation between European community law and national law). In: Forum E, 4/ 1989.

HOCHBAUM, Ingo 1994. Europäische Dimension und europäische Identität: Pedagogische Ziele auf neuen Wegen (European dimension and European identity: Pedagogic goals on new ways). Unpublished manuscript.

HOCHBAUM; Ingo (1993). Neue Wege der Zusammenarbeit. Die Bildungs- und Berufsbildungspolitik in Europa nach Maastricht ( $\mathrm{N}$ ew ways of co-operation. Education and vocational education policy in Europe after Maastricht). In: Bildung und Erziehung 1/ 1993.

LIKET, Theo M.E. (1993). Die europäische Entwicklung im Bildungswesen in niederländischer Sicht (The European development in the education system, in $D$ utch view). In: Bildung und Erziehung 1/ 1993.

MCLEAN, Martin (1993). D as europäische Curriculum (The European curriculum). In: Schleicher K laus (ed.): Zukunft der Bildung in Europa. $N$ ationale $V$ ielfalt und europäische Einheit (Future of education in Europe. $\mathrm{N}$ ational diversity and European unity). D armstadt.

M CLEAN, M artin (1990). Britain and a singe marke Europe Prospects for a common school curriculum. London.

MCLEAN, Martin. Das europäische Curriculum (The European curriculum), noc.cit.

Artikkelin saapui toimitukseen tammikuussa 1996 ja siitä tehtiin periaatteellinen julkaisupäätös. Artikkeli on päivitetty keväällä 1998 ja tehty uusi julkaisupäätös to imituskunnan kokouksessa 12.6.1998. 